\title{
EXPERIMENTAL ANALYSIS OF INLET AIR SWIRL IN DIESEL ENGINE THROUGH RADIAL GROOVED INLET VALVES
}

\author{
Shivaprasad Desai \\ Research Scholar, \\ Mechanical Department \\ RYM Engineering College \\ Bellary, Karnataka, India
}

\author{
Dr. HiregoudarYerrennagoudar \\ Professor, \\ Mechanical Department \\ RYM Engineering College \\ Bellary, Karnataka, India
}

\author{
Ashish Jain \\ PTE department, ARAI, Pune, \\ India
}

\begin{abstract}
This paper comprises an experimental determination [2] of inlet air swirl in a single cylinder four stroke diesel engine through modified inlet valve. The paddle wheel type test rig is used to determine inlet air swirl ratios though different inlet valve lifts. Three varieties of inlet valves are tested to find the swirl ratio number which includes a base inlet poppet valve as a reference base model.. The results are compared with base inlet poppet valve and experimentally Swirl Ratios are analyzed.
\end{abstract}

Keywords - Inlet Air swirl, Engines, Inlet valves, Swirl Test rig

\section{INTRODUCTION}

The air swirl in context to IC engines is defined [11] in many ways by different authors but in a simplest way, we can define it as directional intensity of air flow from inlet port to combustion chamber during suction stroke. In general it is quantified by so many software and experiments [1]. It plays very important role in combustion process as it can make the charge nearly homogeneous in structure, provided good rate of air swirl inside the engine cylinder.

The air swirl can be improved through engine manifolds, inlet ports, inlet valves, piston combustion chambers etc. One of the easiest way to achieve good rate of swirl is by inlet poppet valves [12]. There are many cases in the IC engine inlet air swirl study which uses inlet valves to boost inlet air swirl inside the engine cylinder.

\section{A. Basic Inlet poppet valve}

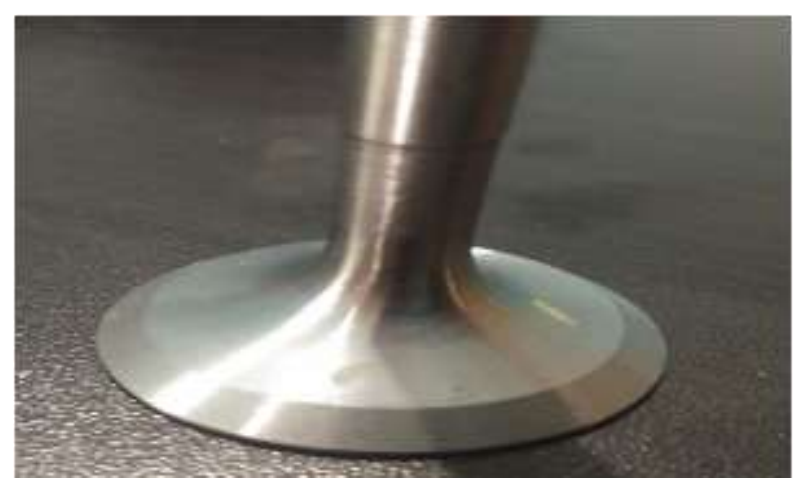

Fig. 1:- Base inlet poppet valve
The typical base model of Kirloskar oil engines AV-1 series engine inlet poppet valve is as shown in the figure. The base inlet poppet valve is machined at seating surface through CNC machines. The valves along with engine head assembly is taken to experiment [3][4][5][6][7][8] the inlet air flow in Paddle type air swirl test rig.

\section{METHODOLOGY}

The methodology can be briefed in following steps:

A. Machining radial grooves on valve seat surface using CNC machines.

B. Testing the machined inlet valves in Swirl Test Rigs

C. Calculating the Swirl numbers for each inlet valve

D. Comparing the Swirl numbers of machined valves with that of base inlet valve

E. Analyzing the improvements in swirl numbers.

\section{A. Machining radial grooves on valve seat surface} using CNC machines.

For machining on valves, the design selected is of radial grooves split in two and three segments. The valves are machined as per the design and experimented in test rigs.

a) Two Radially Grooved Inlet valve

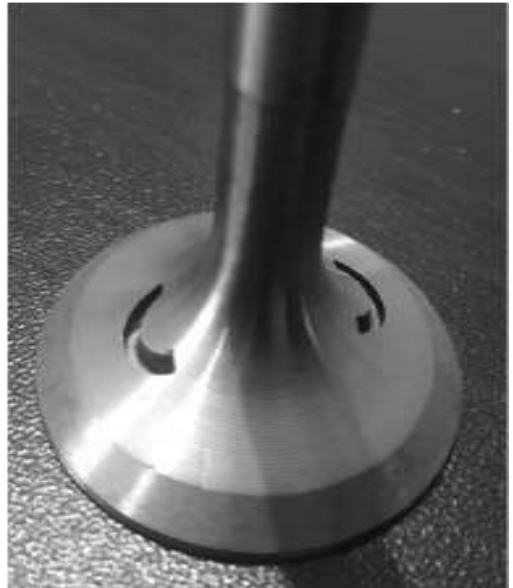

Fig. 2:- Two radially Grooved inlet poppet valve

The base inlet valve is machined on seating surface as shown in figure. The Copper tool is used for making groove on valve seat through electric press CNC. 


\section{International Journal of Engineering Applied Sciences and Technology, 2019 \\ Vol. 4, Issue 3, ISSN No. 2455-2143, Pages 464-469 \\ Published Online July 2019 in IJEAST (http://www.ijeast.com)}

A. Three Radially Grooved Inlet Poppet Valve

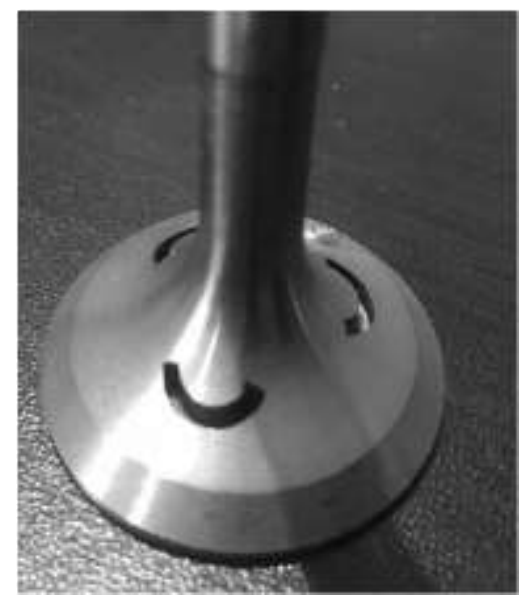

Fig. 3:- Three radially Grooved inlet poppet valve

The base inlet valve is machined on seating surface as shown in figure. The Copper tool is used for making groove on valve seat through electric press CNC.

\section{B. Testing the machined inlet valves in Swirl Test Rigs}
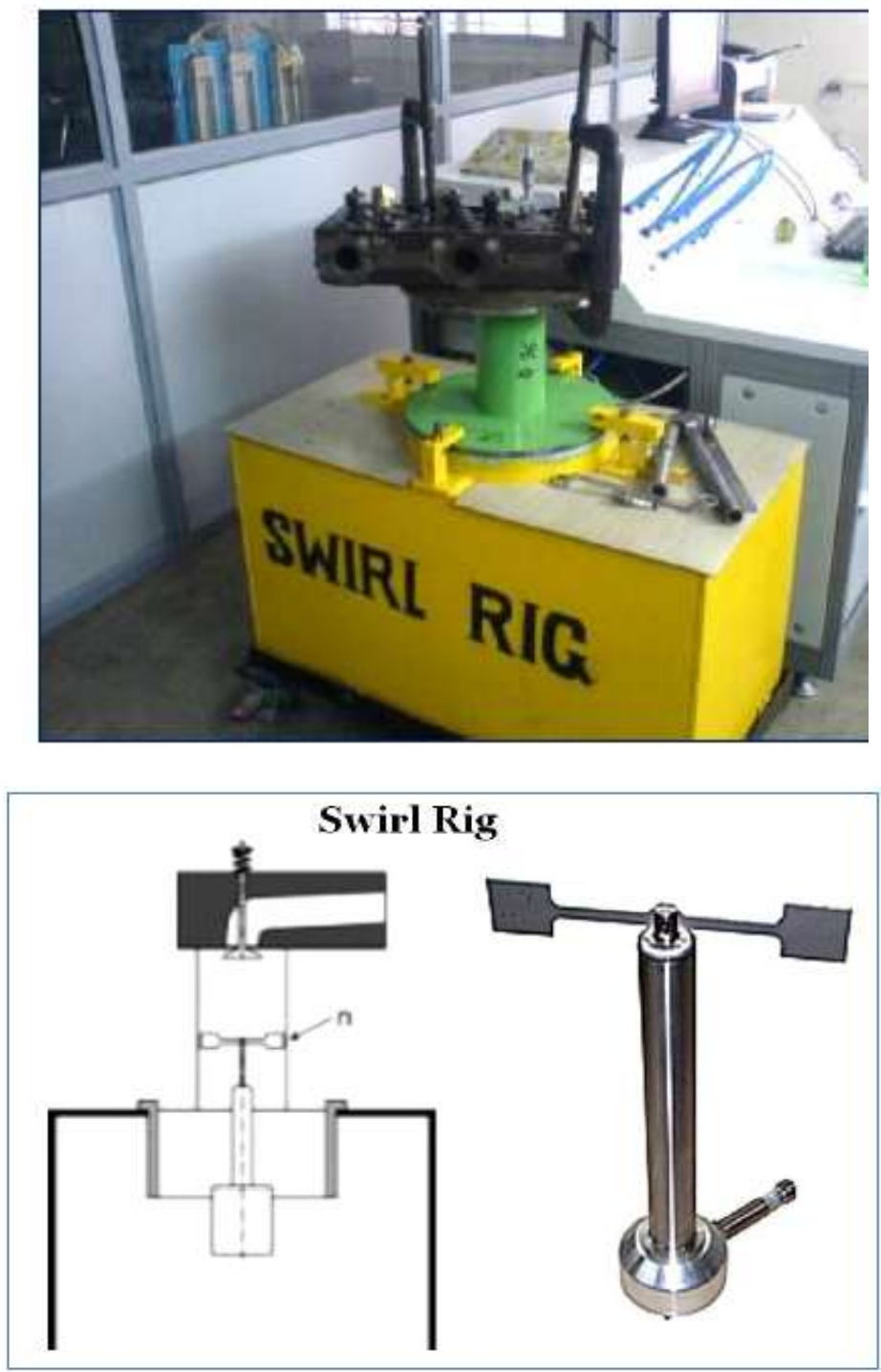

The test rig consists of a Vacuum tank, which holds a Paddle wheel on the top. The Paddle wheel rotates in accordance to the air flowing through port geometry is connected to the DAS which displays the speed of paddle wheel. The blower, motor with variable speed drive, controls the speed of the motor and blower so that the vacuum pressure in tank can be maintained constant. The bore of the dummy liner, which is used to mount the cylinder head is equals to the cylinder bore diameter. Valve lift can be increased or decreased with the help of the depth micrometer fitted on Intake / exhaust valve of cylinder head. (Figure-1 shows the Picture of the Swirl Rig) During intake port testing the air is sucked into the vacuum tank, the blower speed is controlled so that pressure inside the vacuum tank is maintained constant. For set of higher valve lifts (upto $5 \mathrm{~mm}$ lift) a pressure of 250 (mm of water) is maintained. As the valve lift value decreases $(4 \mathrm{~mm}$ onwards) a higher pressure of order 600 ( $\mathrm{mm}$ of water) in the tank is selected and maintained for further valve lifts. For exhaust port testing, a constant level of 500 ( $\mathrm{mm}$ of water) is maintained.

\section{Procedure:}

1. The Cylinder head / Flow Box port is mounted on dummy liner whose diameter equals to the Bore diameter.

2. The valve lift [9]is decreased gradually with the help of depth micro meter, pressure drop across the tank is maintained at 250 ( $\mathrm{mm}$ of water) then pressure drop before the orifice plate, pressure drops across the orifice and paddle wheel speed is obtained from DAS and manometer respectively.

3. The procedure in step 2 is repeated for the subsequent readings of higher values of valve lifts.

4. The valve lift decreases to lower values then the tank pressure to maintain is increased from 250 to $600 \mathrm{~mm}$ of water as a standard procedure, the other parameter like pressure drop before the orifice plate, pressure drops across the orifice and paddle wheel speed is obtained from DAS and manometer respectively.

5. The readings are obtained and these values are fed into ARAI developed software to obtain the mean swirl and mean flow rate values.

\section{a) Diesel Engine Details}

Water cooled, single cylinder, 4-stroke diesel

$$
\begin{aligned}
& \mathrm{BHP}=5 \mathrm{HP} \quad=3.68 \mathrm{KW} \\
& \text { Bore Diameter }=80 \mathrm{~mm} \\
& \text { Stroke length }=110 \mathrm{~mm} \\
& \text { Speed }
\end{aligned}
$$

Compression ratio $=16.5: 1$ 
International Journal of Engineering Applied Sciences and Technology, 2019

Vol. 4, Issue 3, ISSN No. 2455-2143, Pages 464-469

Published Online July 2019 in IJEAST (http://www.ijeast.com)

b) Table-1:Tabulated Readings from Swirl Test Rigs

\begin{tabular}{|c|c|c|c|c|c|c|}
\hline $\begin{array}{c}\text { Valve } \\
\text { Lift }\end{array}$ & L/D Ratio & $\begin{array}{l}\text { Up Stream } \\
\text { Pressure (P1) }\end{array}$ & $\begin{array}{l}\text { Mass Flow } \\
\text { Rate }\end{array}$ & Swirl Ratio & Paddle wheel Speed & Mean Swirl \\
\hline $\mathrm{mm}$ & Number & $\mathrm{mm}$ of water & lit/sec & Number & RPM & Number \\
\hline \multicolumn{7}{|c|}{ Base inlet valve } \\
\hline 12 & 0.382409 & 254 & 17.19892499 & 1.854091091 & 1716 & \multirow{3}{*}{2.000125} \\
\hline 8 & 0.254939 & 254 & 17.19892499 & 1.841125419 & 1704 & \\
\hline 4 & 0.12747 & 606 & 23.52449618 & 0.867815771 & 1086 & \\
\hline \multicolumn{7}{|c|}{ Two Radially Grooved Inlet Valve } \\
\hline 12 & 0.382409 & 254 & 17.19892499 & 1.905953779 & 1764 & \multirow{3}{*}{1.948735} \\
\hline 8 & 0.254939 & 254 & 17.19892499 & 1.763331388 & 1632 & \\
\hline 4 & 0.12747 & 607 & 23.52582596 & 0.925402826 & 1158 & \\
\hline \multicolumn{7}{|c|}{ Three Radially Grooved Inlet Valve } \\
\hline 12 & 0.382409 & 254 & 17.19892499 & 1.880022435 & 1740 & \multirow{3}{*}{2.027010} \\
\hline 8 & 0.254939 & 254 & 17.19892499 & 1.854091091 & 1716 & \\
\hline 4 & 0.12747 & 606 & 24.29599518 & 0.919178362 & 1188 & \\
\hline
\end{tabular}

C. Calculating the Swirl numbers for each inlet valve:

$S R=\frac{N_{\text {paddle }}}{N_{\text {motor }}}$

$S R=\frac{\rho \cdot A \cdot S \cdot N_{\text {paddle }}}{30 \cdot \dot{m}}$

$\mathrm{SR}=$ Swirl Ratio, in numbers

$\rho=$ Density of Air $=1.225 \mathrm{~kg} / \mathrm{m}^{3}$

$A=\frac{\pi \cdot D^{2}}{4}$

$\mathrm{D}=$ Diameter of Bore in $\mathrm{m}$

$N_{\text {paddle }}=$ Paddle wheel RPM

$\mathrm{S}=$ Stroke Length in $\mathrm{m}$

$m^{\cdot}=$ Mass flow rate of air in $\mathrm{kg} / \mathrm{sec}$

$N_{\text {Motor }}=$ Engine speed in $R P M$ 
D. Comparison of Swirl numbers of machined valves with that of base inlet valve
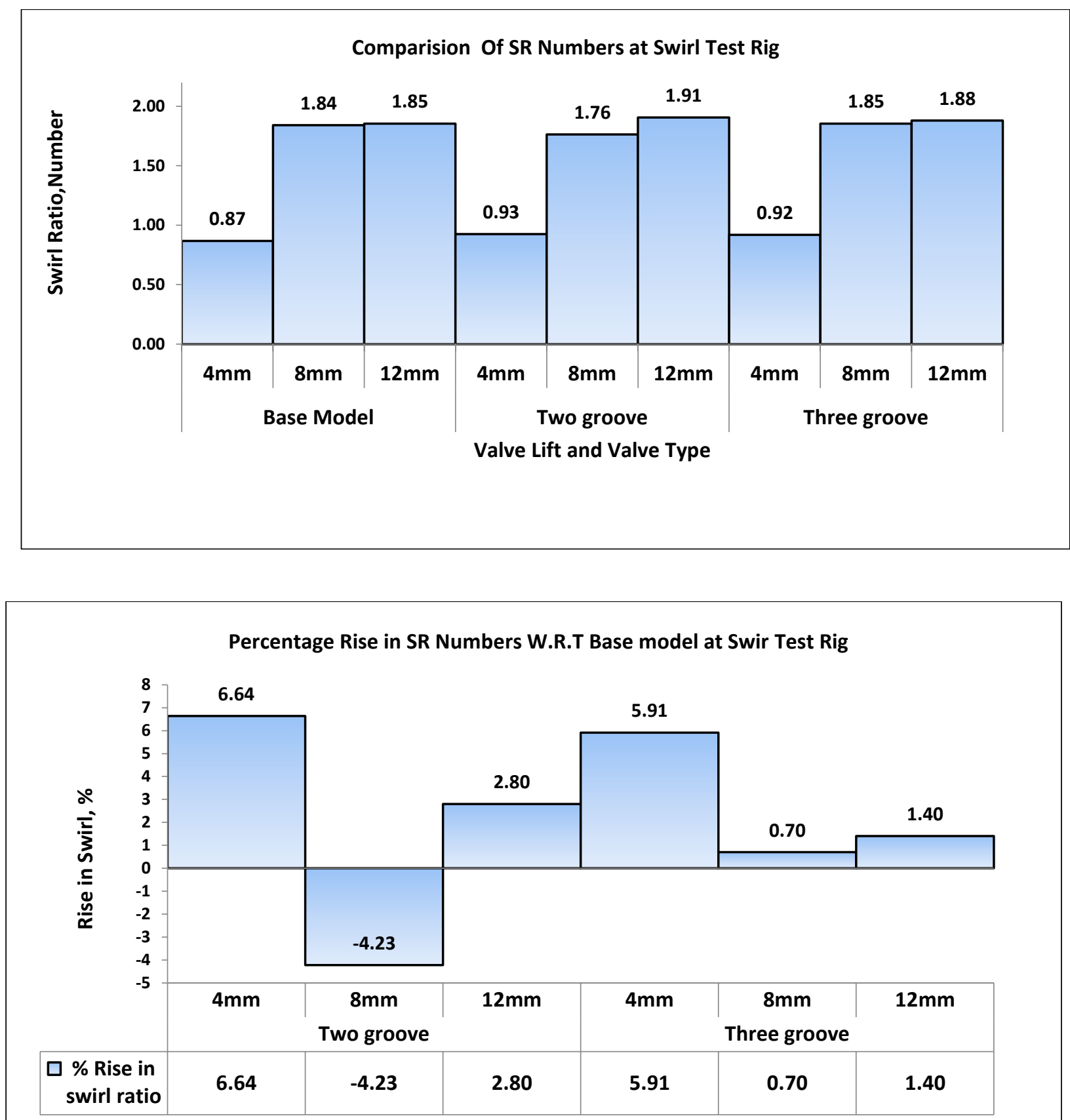

\section{RESULTS AND DISCUSSION}

Swirl test rig results infer the following points:

1. The Two Radially Grooved inlet poppet valve exhibits an improvement in swirl ratio at $4 \mathrm{~mm}$ and $12 \mathrm{~mm}$ inlet valve lifts as compared with base inlet poppet valve.
2. The Three Radially Grooved Inlet poppet valve exhibits better swirl ratios compared to base inlet valve.

3. At all valve lift, the three grooved inlet valve is providing an improved swirl ratio inside the engine cylinder.

4. The following table gives idea about improvement in swirl ratio when compared with base inlet poppet valve. 


\section{International Journal of Engineering Applied Sciences and Technology, 2019 \\ Vol. 4, Issue 3, ISSN No. 2455-2143, Pages 464-469 \\ Published Online July 2019 in IJEAST (http://www.ijeast.com)}

5. One can understand easily from above table that there is $5 \%$ to $6.5 \%$ increment found in swirl ratios through radially grooved inlet poppet valves
6. The reduction in swirl number for Two grooved inlet valve at $8 \mathrm{~mm}$ valve lift is to be analyzed further

\begin{tabular}{|c|c|c|c|c|}
\hline \multirow{2}{*}{ Type of valve } & Valve lift & Swirl Ratio & $\begin{array}{c}\text { Variation with } \\
\text { Base inlet } \\
\text { Valve }\end{array}$ & $\begin{array}{c}\text { \% Rise in } \\
\text { Swirl ratio } \\
\text { Number }\end{array}$ \\
\hline \multirow{3}{*}{ Base model } & $12 \mathrm{~mm}$ & 1.854091 & & \\
\cline { 2 - 5 } & $8 \mathrm{~mm}$ & 1.841125 & & \\
\cline { 2 - 5 } & $4 \mathrm{~mm}$ & 0.867816 & & $\mathbf{2 . 7 9 7 2 0 3}$ \\
\hline \multirow{3}{*}{ Two groove } & $12 \mathrm{~mm}$ & 1.905954 & 0.051863 & -4.22535 \\
\cline { 2 - 5 } & $8 \mathrm{~mm}$ & 1.763331 & -0.07779 & $\mathbf{6 . 6 3 5 8 6 2}$ \\
\cline { 2 - 5 } & $4 \mathrm{~mm}$ & 0.925403 & 0.057587 & $\mathbf{1 . 3 9 8 6 0 1}$ \\
\hline \multirow{3}{*}{ Three groove } & $12 \mathrm{~mm}$ & 1.880022 & 0.025931 & $\mathbf{0 . 7 0 4 2 2 5}$ \\
\cline { 2 - 5 } & $8 \mathrm{~mm}$ & 1.854091 & 0.012966 & $\mathbf{5 . 9 1 8 6 0 5}$ \\
\cline { 2 - 5 } & $4 \mathrm{~mm}$ & 0.919178 & 0.051363 & \\
\hline
\end{tabular}

\section{CONCLUSIONS}

1. The inlet air swirl in engine cylinder can be intensified through inlet poppet valves.

2. By modification in inlet valve seat surface, the Swirl Ratios can be varied.

3. Two and Three radial grooved inlet valve can increase swirl ratio by 4 to $6 \%$ compared to Base inlet valve.

4. Test rig results are considered before designing a inlet poppet valves.

5. It is easy to machine inlet poppet valves than machining of engine heads and pistons to intensify the rate of swirl.

6. Statistical analysis of test rig experiments for swirl ratios can be validated with number of trials.

\section{FUTURE RECOMMENDATIONS}

1. The Swirl test rig can be used to analyze computational methods to determine the swirl ratios.

2. Optical study of in-cylinder air motion can be implemented to investigate inlet air swirl.

3. The valves can machined and experimented through specific paddle wheel type air swirl testing rigs.

4. A modified inlet valve can be assembled to engine to test its performances.

\section{REFERENCES}

[1] Forte Claudioa, Catellani Cristiana, "Numerical Evaluation of the Applicability of Steady Test Bench Swirl Ratios to Diesel Engine Dynamic Conditions" 69th Conference of the Italian Thermal Engineering Association, (ATI 2014)

[2] Federico Brusiani "Tumble motion generation in small gasoline engines: a new Methodological approach for the analysis of the influence of the Intake duct geometrical parameters" 68th Conference of the Italian Thermal Machines Engineering Association, (ATI2013)

[3] El-Adawy M. (2017) "Experimental study on an IC engine in-cylinder flow using different steady-state flow benches "Alexandria Engineering Journal 56, 727-736

[4] Cristian Catellania (2016) "Large Eddy simulation of a steady flow test bench using OpenFOAM". 71st Conference of the Italian Thermal Machines Engineering Association, ATI2016, 14-16 September 2016, Turin, Italy

[5] LIN Man-"Steady flow test and numerical simulation of a GDI engine". 2nd International Conference on Electronic \& Mechanical Engineering and Information Technology (EMEIT-2012)

[6] Pankaj N. "Swirl Induction with Dimpled Cylinder Head and its Effect on Exhaust Emission of Diesel Engine." International Journal of Science and Research (IJSR) ISSN (Online): 2319-7064

[7] Mohiuddin A.K.M. (2011) "Investigation of the swirl effect on engine Using designed swirl adapter." IIUM Engineering Journal, Special Issue, Mechanical Engineering,

[8] Gosavi G.S. "Swirl measuring equipment for direct Injection diesel engine". International Journal of Advance Research in Science and Engineering.

[9] Tianyou Wang "Effects of Variable Valve Lift on InCylinder Air Motion.” Energies

[10] Prasad S.L.V. "Experimental study of the Effect of in cylinder air swirl On diesel engine performance." 
International Journal of Engineering Applied Sciences and Technology, 2019

Vol. 4, Issue 3, ISSN No. 2455-2143, Pages 464-469

Published Online July 2019 in IJEAST (http://www.ijeast.com)

International Journal of Engineering Science and Technology (IJEST).

[11] Heywood JB. "Internal combustion engine fundamentals". New York: McGraw-Hill Book Co., 1982.

[12] Murali Krishna. B (2015) "Experimental investigations of in-cylinder flows of Engine with Intake Shrouded Valve". International Journal of Engineering Technology, Management and Applied Sciences Volume 3, Special Issue, ISSN 2349-4476. 